\title{
The Effect of Initial pH on Pistachio Processing Industrial Wastewater Pre-treatment by Electrocoagulation Method
}

\author{
Serkan Bayar ${ }^{1}$, Alper Erdem Yılmaz ${ }^{1, *}$, Zuhal Köksal, Recep Boncukcuoğlu ${ }^{1}$,Baybars Ali Fil ${ }^{2}$ and \\ Murat Tolga Yilmaz \\ ${ }^{1}$ Department of Department of Environmental Engineering, Faculty of Engineering, University of Atatürk, Erzurum 25240, \\ Turkey \\ ${ }^{2}$ Department of Environmental Engineering, Faculty of Engineering, University of Balıkesir, Balıkesir, 25240, Turkey \\ *Corresponding author
}

\begin{abstract}
In this study, removal of chemical oxygen demand (COD) and total phenols (TP) from pistachio processing industry wastewater was investigated using electrocoagulation method. COD and TP removal efficiencies were compared considering wastewater initial $\mathrm{pH}$ by using stainless steel cathodes and aluminum anodes. To determine the effect of initial $\mathrm{pH}$ on removal efficiency, 4, 5.2 (original wastewater $\mathrm{pH}$ ), 6 and $7 \mathrm{pH}$ were investigated. Results showed that optimum values of operating variables wastewater initial $\mathrm{pH}$ was 5.2 for COD removal efficiency and 7 for TF removal efficiency. Removal of COD of pH 5.2 up has increased. Removal of COD began to decrease at higher $\mathrm{pH}$ values than the original $\mathrm{pH}$ value. TF removal efficiency increased with increasing $\mathrm{pH}$. The $\mathrm{pH}$ values at the obtained the highest energy consumption value was the original $\mathrm{pH}$. The energy consumption value were decreased above and below the original $\mathrm{pH}$ value. The highest removal efficiencies for COD and TF were $\% 60$ and $\% 95$, respectively under operating conditions as $25 \mathrm{ml} / \mathrm{min}$ flow rate and $20 \mathrm{~A}$ current intensity.
\end{abstract}

Keywords-electrocoagulation; Initial pH; removal efficiency; aluminum anode

\section{INTRODUCTION}

Pistachio processing is a rapidly developing industry in Turkey. In 2012, Turkey ranked third among the world's exporters of pistachio products (1). Wastewaters from the pistachio processing industry (PPI) are characterized by high chemical oxygen demand (COD), total organic carbon (TOC), and total phenol (TP) due to their high level of organic contents Pistachio is processed in a wet system in Turkey. In 2012, Turkey produced 120,000 tons of pistachio and the processing industry of pistachio produces approximately $6 \mathrm{~m} 3$ of wastewater per ton of pistachio, which is directly discharged to the sewage system.

EC has been proved to be an efficient method for the treatment of wastewater containing high amounts of organic matter (such as PPIW). It was tested successfully to treat textile wastewater (2), polyvinyl alcohol $(3,4)$, laundry wastewater (5), chemical mechanical polishing wastewater (6), arsenic removal (7), soluble oil wastewater (8), salicylic acid (9), and indium ions (10). EC has also been proposed to treat various food industry wastewaters such as yeast wastewater (11), restaurant wastewater (12), poultry slaughterhouse (13), and olive mill wastewater (14).

Electrochemical methods appear to be effective for the treatment of different effluents compared with conventional methods. Electrocoagulation has many advantages over conventional chemical coagulation, such as simple equipment, easy operation and automation, a short retention time, low sludge production, and no chemical requirement; therefore, it does not produce secondary pollution. Electrocoagulation is the process of destabilizing suspended, emulsified, or dissolved contaminants in an aqueous medium by introducing an electric current ninto the medium (15). Several materials can be used for the anodes, such as $\mathrm{Al}$ and $\mathrm{Fe}$ electrodes in the electrocoagulation process. For example, aluminum anodes have the same effect as the addition of Al based coagulants in conventional treatment systems (16).

The most widely used electrode materials in the electrocoagulation process are aluminum and iron. In the case of aluminum, the main reactions are as follows:

$$
\underline{\mathrm{A} v o \delta \varepsilon}: \mathrm{A} \lambda_{(\sigma)} \rightarrow \mathrm{A} \lambda_{3}^{+}(\alpha \theta)+3 \varepsilon^{\uparrow}
$$

Cathode: $3 \mathrm{H}_{2} \mathrm{O}+3 \mathrm{e}^{-} \rightarrow 3 / 2 \mathrm{H}_{2(\mathrm{~g})}+3 \mathrm{OH}^{-}{ }_{(\mathrm{aq})}$

On the other hand, at higher $\mathrm{pH}$ values, both cathode and anode may be chemically attacked by $\mathrm{OH}^{-}$ions:

$$
2 \mathrm{~A} \lambda_{(\sigma)}+6 \mathrm{H}_{2} \mathrm{O}+2 \mathrm{OH}_{(\alpha \theta)}^{\downarrow} \rightarrow 2 \mathrm{~A} \lambda(\mathrm{OH})_{4}^{\downarrow}(\alpha \theta)+3 \mathrm{H}_{2(\gamma)}
$$

$\mathrm{Al}_{3}^{+}$and $\mathrm{OH}^{-}$ions generated by electrode reactions (1) and (2) react to form various monomeric species such as $\mathrm{Al}(\mathrm{OH})_{2}{ }^{+}$, $\mathrm{Al}(\mathrm{OH})_{2}{ }^{+}, \mathrm{Al}_{2}(\mathrm{OH})_{2}{ }^{2+}, \mathrm{Al}(\mathrm{OH})_{4}^{-}$, and polymeric species such as $\mathrm{Al}_{6}(\mathrm{OH})_{15}{ }^{3+}, \mathrm{Al}_{7}(\mathrm{OH})_{17}{ }^{4+}, \mathrm{Al}_{8}(\mathrm{OH})_{20}{ }^{4+}, \mathrm{Al}_{13} \mathrm{O}_{4}(\mathrm{OH})_{24}{ }^{7+}$, $\mathrm{Al}_{13}(\mathrm{OH})_{34}{ }^{5+}$, which transform finally into $\mathrm{Al}(\mathrm{OH})_{3}(\mathrm{~s})$ according to complex precipitation kinetics (17).

$$
\mathrm{A} \lambda_{3}{ }^{+}(\alpha \theta)+3 \mathrm{H}_{2} \mathrm{O} \square \mathrm{A} \lambda(\mathrm{OH})_{3(\sigma)}+3 \mathrm{H}^{+}{ }_{(\alpha \theta)}
$$

Freshly formed amorphous $\mathrm{Al}(\mathrm{OH})_{3(\mathrm{~s})}$ "sweep flocks" have a large surface area which is beneficial for a rapid adsorption of soluble organic compounds and trapping of colloidal particles. 
Finally, these flocks are removed easily from aqueous medium by sedimentation or $\mathrm{H}_{2}$ flotation.

The objective of the present study is to investigate the efficiency of electrocoagulation pre-treatment of PPIW using aluminum electrode. The effects of operational parameters, namely initial $\mathrm{pH}$ of wastewater, was examined on COD and TP removal efficiency.

\section{MATERIAL AND METHODS}

\section{A. PPIW Effluent}

Wastewater samples used in the present study were obtained from a local pistachio processing plant with the daily capacity of 13 tons and producing approximately $80 \mathrm{~m} 3$ of wastewater a day in the city of Gaziantep (Turkey). Wastewater was filtered using a screen filter to remove large suspended solids before being used for the subsequent studies. Results of the chemical analysis of PPIW are given in Table 1 . The $\mathrm{pH}$ of the wastewater was adjusted to the required value using concentrated nitric acid and sodium hydroxide. All chemicals were at analytical grade and supplied by Merck. COD and TP were determined as proposed by standard methods (18).

The removal efficiency and energy consumption $(4,25)$ in PPIW treated by electrocoagulation is calculated as follows:

$$
\% \text { Removal efficiency }=\frac{C_{0}-C_{t}}{C_{0}} * 100
$$

where $\mathrm{C}_{0}$ is the initial COD and TP value $\left(\mathrm{mg} \mathrm{L}^{-1}\right), \mathrm{C}_{\mathrm{t}}$ is the $\mathrm{COD}$ and $\mathrm{TP}$ value at time.

$$
\text { Energy consumrtion }(W)=\frac{V * I * t}{v}
$$

where $\mathrm{W}$ is the energy consumption $\left(\mathrm{kW}-\mathrm{h} \mathrm{m}^{-3}\right), \mathrm{V}$ is the average cell voltage $(\mathrm{V}), \mathrm{I}$ is the current density $(\mathrm{A}), \mathrm{t}$ is the electrolysis duration $(\mathrm{h})$, and $\mathrm{v}$ is the volume of the wastewater $\left(\mathrm{m}^{3}\right)$.

\section{B. Electrocoagulation Procedure}

The electrocoagulation cell was constructed from stainless steel having an inner diameter of $6 \mathrm{~cm}$ and height of $65 \mathrm{~cm}$. The experimental equipment schematically was shown in Figure 1. The total volume of wastewater used in each experiment was approximately $500 \mathrm{~mL}$. Aluminum (Al) electrode an inner diameter of $5 \mathrm{~cm}$ and height of $70 \mathrm{~cm}$ was used for the sacrificial electrode. The distance between electrodes was fixed at approximately $5 \mathrm{~mm}$. Aluminum electrode had approximately $1130 \mathrm{~cm} 2$ of effective surface. The current was maintained to be constant by means of a precision DC power supply characterized by the ranges from 0 to $40 \mathrm{~A}$ for current and 0 to $120 \mathrm{~V}$ for voltage. Two digital multimeters (Brymen Bm-201; one as ampermeter and the other as voltmeter) were used to measure the current passing through the circuit and the applied potential, respectively. The temperature, conductivity, and $\mathrm{pH}$ of the wastewaters were measured by a multi-parameter (WTW Multiline P-4 F-Set-3) during the experiments. Treated wastewater was collected over a desired period of time from the reactor and the collected samples were filtered by the cellulose acetate membrane filter with the pore diameter of $0.45 \mu \mathrm{m}$ (Schleicher and Schuell) before the analysis. The reactor was operated in continuous and galvanostatic mode.

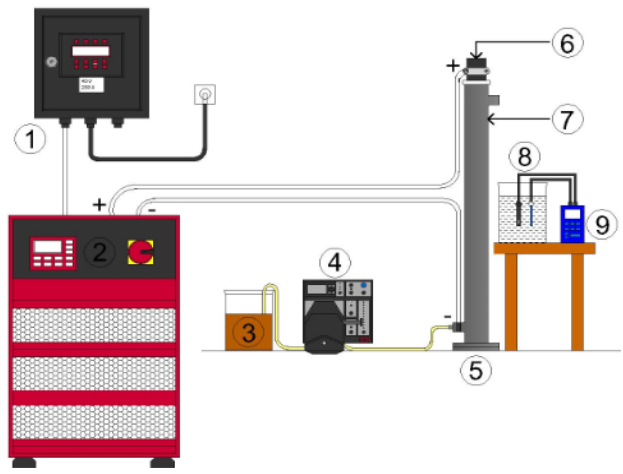

FIGURE I. SCHEMATIC VIEW OF THE EXPERIMENTAL SYSTEM

(1: CONTROL PANEL 2: POWER SUPPLY 3: WASTEWATER INLET CHAMBER 4: PERISTALTIC PUMP 5: REACTOR 6: ANODE ELECTRODE 7: CATHODE ELECTRODE 8: WASTEWATER OUTLET CHAMBER 9: PH CONTROL UNIT)

\section{RESUlts AND DisCUSSIONS}

Initial $\mathrm{pH}$ of wastewater is one of the most important process parameters in electrocoagulation $(19,20)$. Since the $\mathrm{pH}$ of untreated wastewater can affect the stability of hydroxide types, this effect can also be seen on pollutant removal efficiency negatively or positively. Anode and cathode reactions in aqueous solutions can result in alterations of $\mathrm{pH}$ values in solutions. Therefore, electrolytic soluble metal ions depending on wastewater $\mathrm{pH}$ (such as $\mathrm{Al}^{+3}$ and $\mathrm{Fe}^{+2}$ ) can form different hydroxide types with different $\mathrm{pH}$ values (21). In addition, changes in $\mathrm{pH}$ can alter the surface load of particles and this can affect the removal of organic materials dispersed in wastewater (22).

Wastewater with the initial $\mathrm{pH}$ values in the range of 3.0 to 8.0 was used in order to investigate the effect of initial $\mathrm{pH}$ in wastewater on the removal efficiency of COD and TP using aluminum electrode. Experiments were carried out without intervening $\mathrm{pH}$ values during reaction. Throughout the experiment period, constant current intensity was $15 \mathrm{~A}$, flow rate was $100 \mathrm{ml} / \mathrm{min}$ and the temperature was $293 \mathrm{~K}$. Figure 23 represents graphically the results obtained for the removal efficiency of COD and TP.

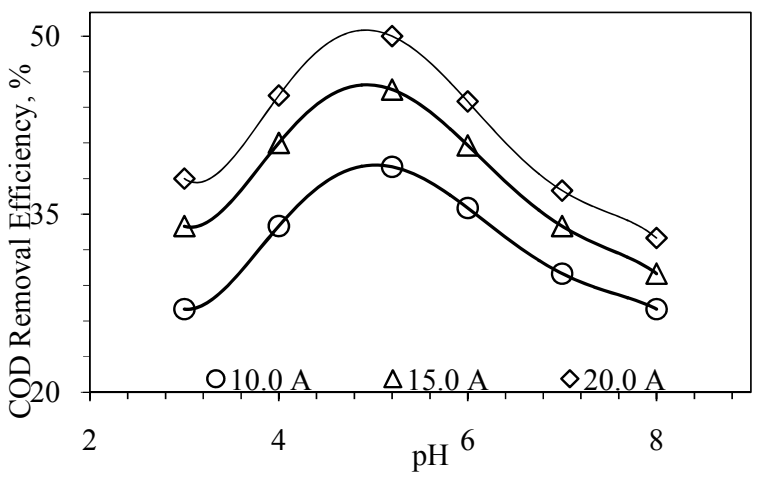

FIGURE II. THE EFFECT OF INITIAL PH ON COD REMOVAL, 30 ML/MIN FLOW RATE, 293 K WASTEWATER TEMPERATURE 


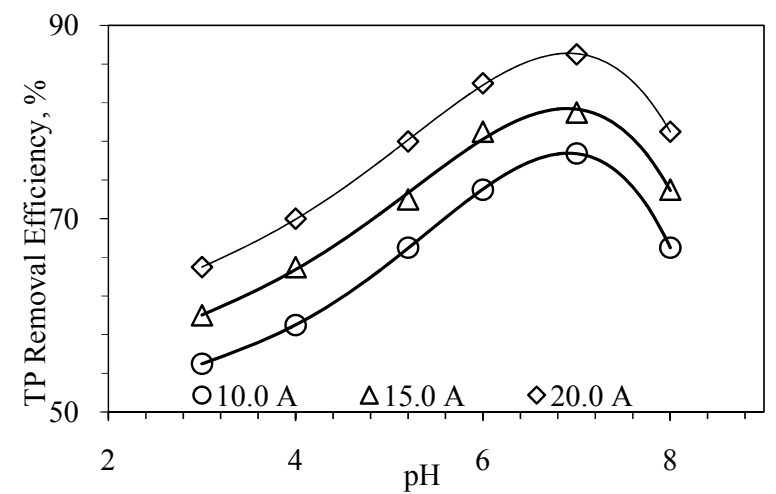

FIGURE III. THE EFFECT OF INITIAL PH ON TP REMOVAL, 30 ML/MIN FLOW RATE, $293 \mathrm{~K}$ WASTEWATER TEMPERATURE

COD removal efficiency values $(\eta)$ obtained after 20 minute reaction period are $40 \%, 45 \%, 50 \%, 45 \%, 37 \%$ and $33 \%$ for initial $\mathrm{pH}$ values ranging from 3 to 8 . The TP removal efficiency values $(\eta)$ were found to be $65 \%, 70 \%, 77 \%, 83 \%$, $88 \%$ and $77 \%$.

When considering Figure 2, it can be seen that COD and TP removal efficiency in wastewater from the pistachio processing industry using the electrocoagulation process is associated strongly with the initial $\mathrm{pH}$ of wastewater. The COD removal efficiency increases when wastewater initial $\mathrm{pH}$ increases from 3 to 5.2 . However, when the initial $\mathrm{pH}$ is higher than 5.2, the removal efficiency decreases consistently and when the initial $\mathrm{pH}$ is 7, COD removal efficiency reach the lowest value. TP efficiency was increased with increasing wastewater $\mathrm{pH}$ values. This situation depends on the type of phenol present in the solution. TP removal takes place in reaction the first time. When Figure 4 was investigated, it was seen that the initial $\mathrm{pH}$ changes during the reaction of waste water. The effluent $\mathrm{pH}$ is increased at the end of the reaction time for investigated all $\mathrm{pH}$ values. The reason of increase the TP removal efficiency by $\mathrm{pH}$ 7 was considered that formation of aluminum hydroxide until the $\mathrm{pH}$ range is to be the highest.

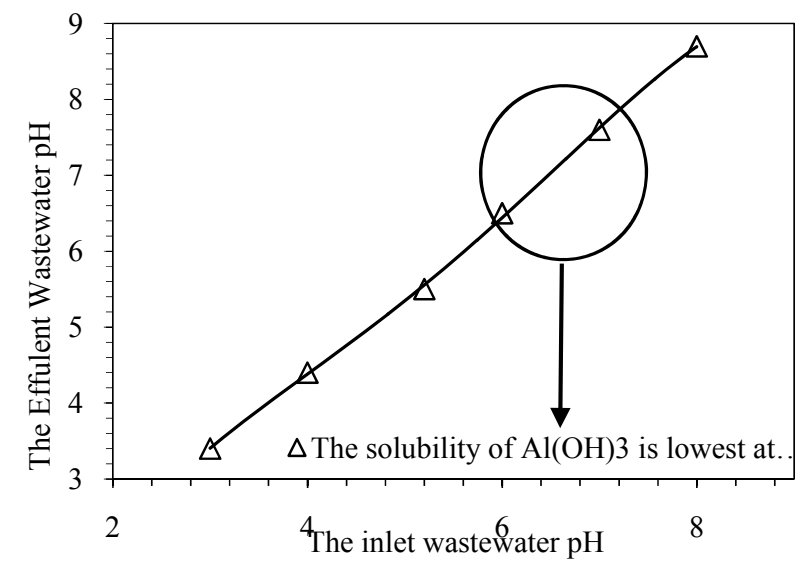

FIGURE IV. THE CHANGES OF PH OF THE WASTE WATER BY ELECTROCHEMICAL REACTION

\section{CONCLUSIONS}

The present study showed the applicability of electrocoagulation method in the pre-treatment of COD and TP from PPIW. The following results were obtained:

Experiments were carried out under uncontrolled $\mathrm{pH}$ (not constant $\mathrm{pH}$ ) conditions ranging from 3.0 to 8.0. The effect of initial $\mathrm{pH}$ on the system performance was evaluated based on the removal efficiency and energy consumption. From the results obtained in the experiments, low initial $\mathrm{pH}$ is suitable for removal efficiency when $\mathrm{pH}$ is not controlled because the solubility of $\mathrm{Al}(\mathrm{OH}) 3$ is minimum in this $\mathrm{pH}$ interval which has a good flocking and weak solving feature. Under optimum conditions as 20 Amper current intensity, $293 \mathrm{~K}$ waste water temperature and $30 \mathrm{ml} / \mathrm{min}$ flow rate, $50 \%$ COD removal and $88 \%$ TP were achieved. The obtained values was indicated that electrocoagulation process was a suitable process for treatment of the pistachio processing industry wastewaters.

\section{REFERENCES}

[1] http://www.tuik.gov.tr.

[2] O.T. Can, M.Kobya, E.Demirbas, M.Bayramoglu. "Treatment of the textile wastewater by combined electrocoagulation" Chemosphere,2006, 62: 181-187.

[3] T.-W. Chih, L-C. Wei, Y-H.Kai.“Treatment of polyvinyl alcohol from aqueous solution via electrocoagulation" Sep Sci Technol, 2010, 45:212-220.

[4] W-L.Chou."Removal and adsorption characteristics of polyvinyl alcohol from aqueous solutions using electrocoagulation" J. Hazard Mater, 2010, 177: 842-850.

[5] F.Janpoor,A. Torabian, V.Khatibikamal."Treatment of laundry waste-water by electrocoagulation" J Chem Technol Biotechnol, 2011, 86: 1113-1120.

[6] C-T. Wang, W-L.Chou."Performance of COD removal from oxide chemical mechanical polishing wastewater using iron electrocoagulation" J Environ Sci Heal A,2009, 44: 1289-1297.

[7] V-K. Sangal, I-M .Mishra, J-P.Kushwaha."Electrocoagulation of soluble oil wastewater: Parametric and kinetic study" Sep Sci Technol. 2012, 48: 1062-1072.

[8] Y-S. Yildız, A-S. Koparal, B.Keskinler. "Effect of initial pH and supporting electrolyte on the treatment of water containing high concentration of humic substances by electrocoagulation" Chem Eng J.,2008, 138: 63-72.

[9] W-L. Chou, C-T. Wang, T-C. Liu, L-C. Chou."Effect of process parameters on removal of salicylic acid from aqueous solutions via electrocoagulation" Envıron Eng Sci, 2011, 28: 365-372.

[10] W-L.Chou, K-Y. Huang. "Electrochemical removal of indium ions from aqueous solution using iron electrodes" J.Hazard Mater, 2009, 172: 46-53.

[11] S. Tchamango, C-P. Nanseu-Njiki, E. Ngameni, D. Hadjiev,A. Darchen."Treatment of dairy effluents by electrocoagulation using aluminium electrodes" Sci Total Environ. 2010, 408: 947-952.

[12] Z-V-P. Murthy, C. Nancy,A. Kant."Separation of pollutants from restaurant wastewater by electrocoagulation" Sep Sci Technol. 2007, 42: 819-833.

[13] S. Bayar, Y-S.Yıldız, A-E. Yılmaz, S.Irdemez. "The effect of stirring speed and current density on removal efficiency of poultry slaughterhouse wastewater by electrocoagulation method" Desalination. 2011, 280: 103-107.

[14] F. Hanafi, O. Assobhei, M. Mountadar. "Detoxification and discoloration of Moroccan olive mill wastewater by electrocoagulation" J Hazard Mater. 2010, 174: 807-812. 
[15] M-M. Emamjomeh,M.Sivakumar."Review of pollutants removed by electrocoagulation and electrocoagulation/flotation processes" J Environ Manage.2009, 90: 1663-1679.

[16] S. Top, E Sekman,S. Hosver, M.S Bilgili, "Characterization and electrocaogulative treatment of nanofiltration concentrate of a full-scale landfill leachate treatment plant" Desalination.2011, $268,158-162$

[17] Y-S. Yildiz, A-S. Koparal, S.Irdemez, B.Keskinler."Electrocoagulation of synthetically prepared waters containing high concentration of NOM using iron cast electrodes" J Hazard Mater. 2007.139: 373-380.

[18] APHA (1998) Standard Methods for the Examination of Water and Wastewater; 20th ed.; AWWA.

[19] N. Adhoum, L.Monser."Decolourization and removal of phenolic compounds from olive mill wastewater by electrocoagulation” J. Chem. Eng. Process. 2004, 43: 1281-1287.

[20] M. Kumar, F-I-A. Ponselvan, J-R. Malviya, V-C Srivastava, ID,Mall."Treatment of bio-digester effluent by electrocoagulation using iron electrodes" J Hazard Mater.2009, 165: 345-352.

[21] M-Y-A. Mollah, R. Schennach, J-R. Parga, DL.Cocke."Electrocoagulation (EC): Science and applications" J Hazard Mater. 2001, 84: 29-41.

[22] P. Drogui, M. Asselin, S-K. Brar, H. Benmoussa, JF.Blais."Electrochemical removal of pollutants from agroindustry wastewaters" Sep Purif Technol.2008, 61: 301-310. 